\title{
SiM
}

\section{Can We Predict Forage Nutritive Value With Weather Parameters?}

\author{
By Kim McCuistion, Michael Grigar, David B. Wester, Ryan Rhoades, Clay Mathis, and \\ Luis Tedeschi
}

\section{On the Ground}

- The use of easily accessible information to forecast when standing forage may lack nutrients to sustain cattle production could be valuable to the ranching community.

- Our study was designed to determine if forage crude protein and acid detergent fiber could be reasonably predicted using precipitation, season, and temperature.

- In south Texas, monthly precipitation in the fall accounted for $63 \%$ of the variation in crude protein and $73 \%$ of the variation in acid detergent fiber.

- A better understanding of how forage nutritive value changes over the year can improve strategic supplementation efforts.

Keywords: forage quality, nutritive value, strategic supplementation, seasonal precipitation.

Rangelands 36(1):2-9

doi: 10.2111/RANGELANDS-D-13-00055.1

(C) 2014 The Society for Range Management

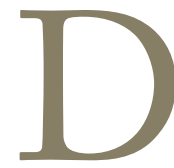

eveloping management practices to better utilize forage resources can improve cattle performance and efficiency. Cattle operations that utilize rangelands depend on rainfall distribution, forage quality, stocking rates, and various other management practices. In the cow/calf phase of the cattle industry, forages supply the majority of the crude protein (CP) and energy to meet cattle nutrient requirements. Forages in south Texas have been reported to be deficient in digestible energy and $\mathrm{CP}$ for lactating cows and marginal for dry cows at certain times of the year. ${ }^{1}$ A challenge for grazing cattle operations is maintaining a nutritionally adequate forage base throughout the entire year. ${ }^{2}$ The ability to use easily accessible information to predict when standing forage may lack the nutrients to sustain cattle production could be valuable to the ranching community.

\section{The Situation}

It is important to understand how range forage nutritive value and cattle nutrient requirements change over time. Allen and Segarra $^{3}$ defined forage quality as the degree to which a forage meets the nutritional requirements of a specific kind and class of animal. If forage quality alone is not able to meet cattle nutrient demands, then supplementation can be provided to bridge the gap and achieve desired performance objectives of the ranching operation. Figure 1 provides an example of the nutritional gap that can occur between forage and a spring or fall calving cow herd in south Texas. At certain times of the year, $\mathrm{CP}$ intake requirements of these cows are not met by the forage alone; consequently, cattle production will be reduced unless supplemental CP is provided.

With the cost of supplemental feeds increasing, especially during times of drought, it is important to know when to begin supplementing to maintain management objectives. A better understanding of range forage nutritive value can improve strategic supplementation outcomes. Forage testing costs money and takes time, but the expenses may be necessary in order to make better management decisions. ${ }^{4}$ If simple weather parameters can be used to predict the nutritive value of forage, ranchers could save time and money when determining if supplementation is needed. Other authors have found that current seasonal rainfall can be useful in predicting forage yield and subsequently used to make stocking rate decisions ${ }^{5,6}$; however, there is limited information that correlates historical weather patterns to forage quality. Consequently, the objective of our study is to determine if the forage nutritive value parameters of $\mathrm{CP}$ and acid detergent fiber (ADF) can be reasonably predicted by precipitation, season, and temperature in south Texas.

\section{Study Site Description}

We conducted our study on a ranch near Kingsville, Texas between 2006 and 2011. The climate in the region is mild, with short winters and warm temperatures throughout the year. Average annual rainfall is $74 \mathrm{~cm}$. Rainfall patterns are historically bimodal, with the highest probability of rainfall during May/June and September; January and February have 

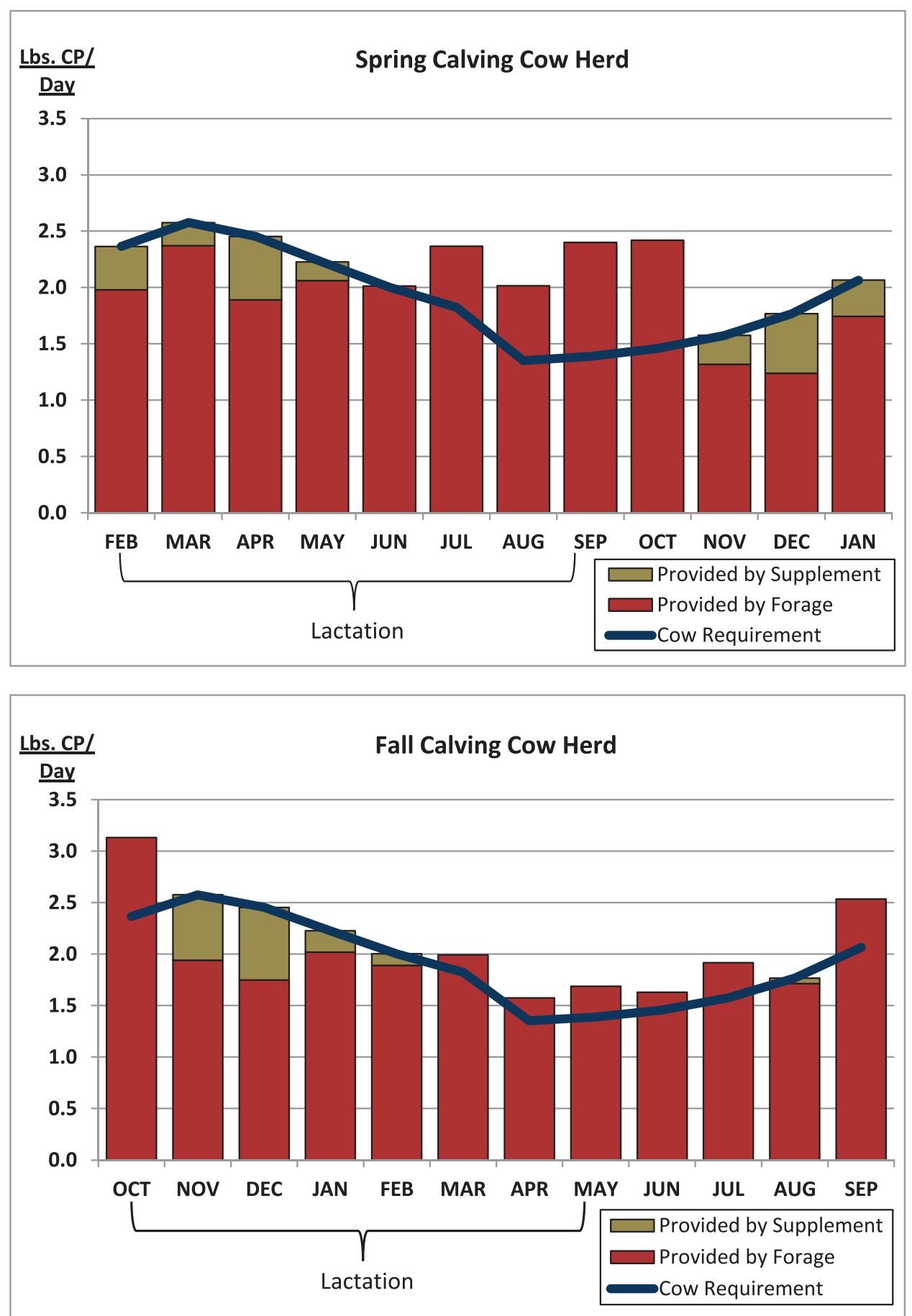

Figure 1. Examples of when spring (Fig. 1a) and fall (Fig. 1b) calving cow herd nutrient requirements for crude protein (CP) are met by the forage alone or in combination with a supplement in south Texas.

the lowest average annual rainfall. It is common for drought and/or long rainless periods to occur throughout the year.

The southern region of Texas is classified as a subtropical climate with an average growing season of 314 days. ${ }^{7}$ Temperate grasses, located in the High Plains of the United States, are generally better in nutritional values when compared to tropical grasses grown in this region of Texas. South Texas forages typically reach their highest nutritional value in spring and fall due to the amount of precipitation and moderate temperatures. Summer and winter nutritional values are generally low due to high temperatures and dormancy, respectively.

\section{What We Did}

Collect Forage

We collected forage grab samples for six consecutive years to determine the nutritive value of forage in grazed pas- 


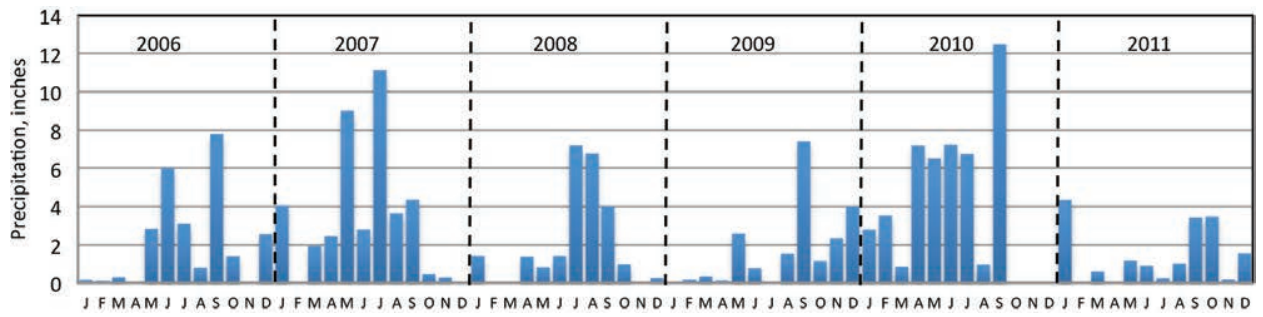

Figure 2. Annual average precipitation in inches by month for pastures where forage was collected.

tures. Forage grab samples were acquired from one of three pastures every month, depending on which pasture 161 Santa Gertrudis cows were grazing. The three pastures were predominately a mix of coastal bermudagrass (Cynodon dactylon L. Pers) and Kleberg bluestem (Dichanthium annulatum (Forssk.) Stapf), but other regional rangeland species were present as well. The average size of sampled pastures was 550 acres with a $70 \%$ forage cover and 30\% brush canopy.

Each month, we collected forage grab samples to mimic the forage consumed by cattle. On the day of collection, we observed cattle grazing a specific area and once cattle moved from that area, we considered evidence of forage type and selectivity. We then collected forage grab samples using a hand-plucking technique to mimic forage consumption patterns of the observed animals. ${ }^{8}$ If cattle were not grazing at the time of collection, we used observed signs of recent grazing activity as a guide to grab sample collection.

\section{Nutritional Analysis of Forage}

Forage samples were stored at $-20^{\circ} \mathrm{C}$ prior to nutrient analysis by Cumberland Valley Analytical Services (Hagerstown, MD 21742, USA). Samples were analyzed using wet chemistry for dry matter, $\mathrm{CP}$, and ADF. We chose these metrics because they are commonly used to describe forage nutritive value. Crude protein was measured because protein is typically the first limiting nutrient in ruminant diets and is relatively simple to measure. ${ }^{9}$ Acid detergent fiber is extensively used in estimating the amount of fiber in diets and values that appear on forage reports. ${ }^{10}$ Both $\mathrm{CP}$ and $\mathrm{ADF}$ are often used in equations to predict total digestible nutrients (TDN).

\section{Determine Precipitation and Temperature}

Daily precipitation amounts were obtained from the ranch. We used rain gauges closest to the three pastures where forage was collected to determine the average amount of precipitation received per pasture. We calculated monthly precipitation totals from daily rainfall records. Figure 2 presents average monthly precipitation amounts between 2006 and 2011; average annual rainfall ranged from 17 inches in 2011 to 48 inches in 2010. Monthly mean temperatures were obtained from Kingsville Naval Air Station, latitude $27.5^{\circ} \mathrm{N}$ and longitude $97.9^{\circ} \mathrm{W}$.

\section{How We Analyzed the Data}

We used a three-step process to determine if forage nutritive value could be predicted from precipitation, season, and temperature. Each step added new information and built upon the model developed in the previous step.

\section{Did Precipitation Affect Forage Nutritive Value?}

In a preliminary examination of the data, we used a simple linear regression analysis to predict forage nutritive value components ( $\mathrm{CP}$ and $\mathrm{ADF}$ ) using precipitation. Preliminary analyses indicated that assumptions underlying this statistical method were satisfied by the data. These analyses were based on simple linear regression of forage nutritive value metrics $(\mathrm{CP}$ and $\mathrm{ADF})$ as related to:

- current month's precipitation

- current+ previous month's precipitation

- current + previous + second previous month's precipitation

- previous month's precipitation

- previous month + second previous month's precipitation

We chose these models because of the potential lag in forage growth, and subsequent nutritive value changes, given rainfall events. The best fitted model was then used for further analysis.

\section{Did Season Affect Forage Nutritive Value?}

The initial regression analyses explored the relationship between forage nutritive value and monthly precipitation regardless of season. To account for seasonal effects, the following seasons were defined ${ }^{11}$ :

- Winter-December, January, and February

- Spring-March, April, and May

- Summer-June, July, and August

- Fall-September, October, and November

We then modeled forage nutritive value as a function of current monthly precipitation with season as a classification variable. This allowed for a test of the hypothesis that the relationship between forage nutritive value and current monthly precipitation varied over the different seasons of data collection.

\section{Did Temperature Affect Forage Nutritive Value?}

Our final analyses focused on multiple linear regression to explain variation in forage nutritive value among seasons with 
Table 1. Simple linear regression of forage nutritive value metrics, crude protein and acid detergent fiber, compared to five different precipitation models $(n=47)$

\begin{tabular}{|c|c|c|c|c|}
\hline \multirow[b]{2}{*}{ Precipitation* } & \multicolumn{2}{|l|}{ CP } & \multicolumn{2}{|l|}{ ADF } \\
\hline & Equation $^{\dagger}$ & $R^{2}$ & Equation & $\begin{array}{c}\text { Adjusted } \\
\text { coefficient of } \\
\text { determination }\end{array}$ \\
\hline $\mathrm{CM}$ & $\hat{Y}=6.88+1.79 X_{1}$ & 0.37 & $\hat{Y}=47.50-2.84 X_{1}$ & 0.19 \\
\hline $\mathrm{CM}+\mathrm{PM}$ & $\hat{Y}=6.59+1.67 X_{1}+0.43 X_{2}$ & 0.38 & $\hat{Y}=48.44-2.45 X_{1}-1.37 X_{2}$ & 0.22 \\
\hline $\begin{array}{l}\mathrm{CM}+\mathrm{PM}+ \\
\mathrm{SPM}\end{array}$ & $\begin{array}{l}\hat{Y}=6.57+1.67 X_{1}+0.41 X_{2}+ \\
0.04 X_{3}\end{array}$ & 0.36 & $\begin{array}{l}\hat{Y}=48.98-2.41 X_{1}- \\
1.05 X_{2}-0.94 X_{3}\end{array}$ & 0.23 \\
\hline PM & $\hat{\gamma}=7.73+0.88 X_{2}$ & 0.08 & $\hat{Y}=46.77-2.04 \mathrm{X}_{2}$ & 0.09 \\
\hline $\mathrm{PM}+\mathrm{SPM}$ & $\hat{Y}=7.67+0.84 X_{1}+0.10 X_{2}$ & 0.06 & $\hat{Y}=47.38-1.68 X_{1}-1.02 X_{2}$ & 0.10 \\
\hline
\end{tabular}

independent variables as current monthly precipitation and average monthly temperature.

\section{What We Learned}

Environmental conditions can affect forages in a variety of ways. Important environmental factors that affect forage quality and quantity are precipitation, temperature, and season. ${ }^{5,711}$ The effect of one or a combination of environmental factors can cause a change in forage quality.

\section{Current Monthly Precipitation}

Based on model fit from the preliminary analyses, we concluded that the simple linear regression models using "cur- rent month's precipitation" were appropriate for more detailed analyses. Although there were positive relationships, considerable variability in forage nutritive value not associated with current monthly precipitation reduced the amount of variation that could be explained (Table 1). The model based on current month's precipitation alone explained $37 \%$ of the variation in forage CP (Fig. 3a). Likewise, current month's precipitation accounted for $19 \%$ of the variation associated with forage ADF (Fig. 3b). In addition to precipitation, other factors can affect forage nutritive value such as precipitation timing, amount per rainfall event, and growth stage of the forage.

Precipitation, or lack thereof, is an environmental factor that affects forage quality and quantity. Drought can elicit
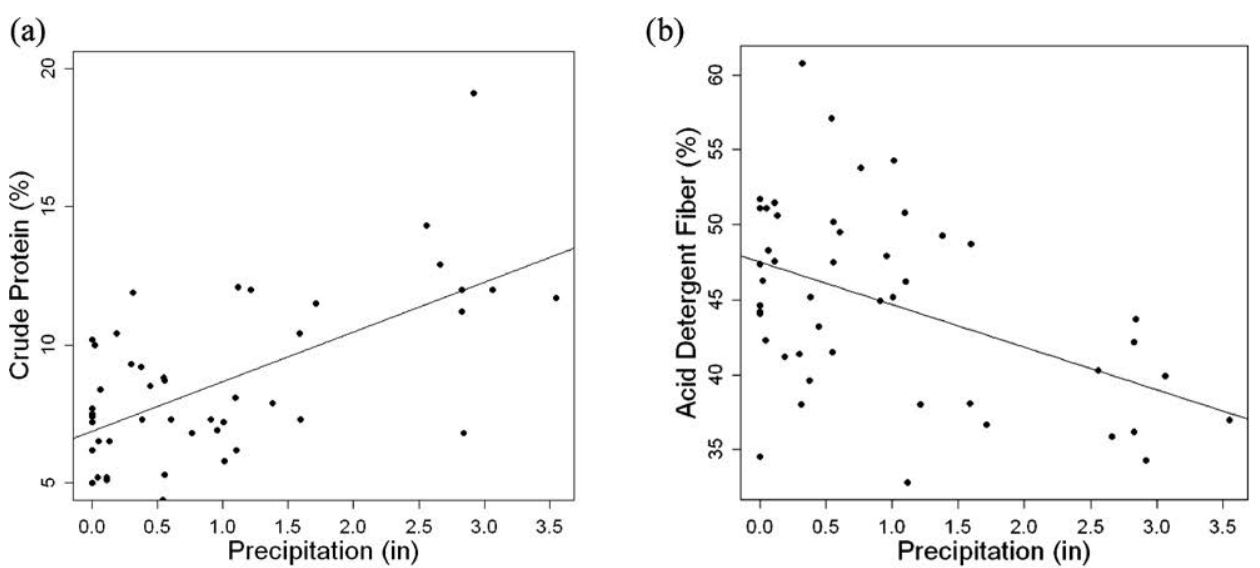

Figure 3. Initial regression analysis comparing forage crude protein (Fig. 3a) and acid detergent fiber (Fig. 3b) to precipitation amounts; see Table 1 for regression equation. 
(a)

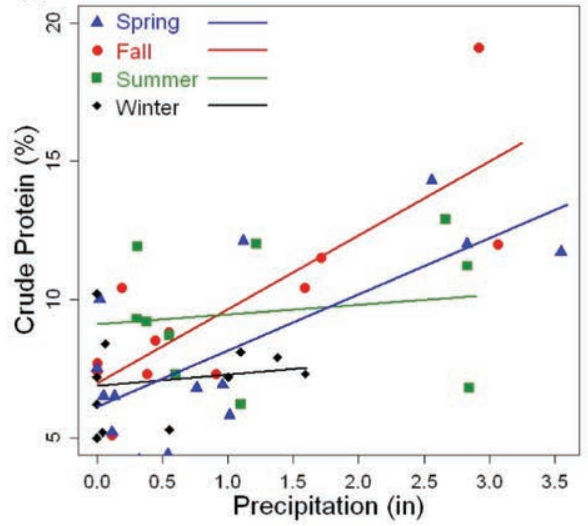

(b)

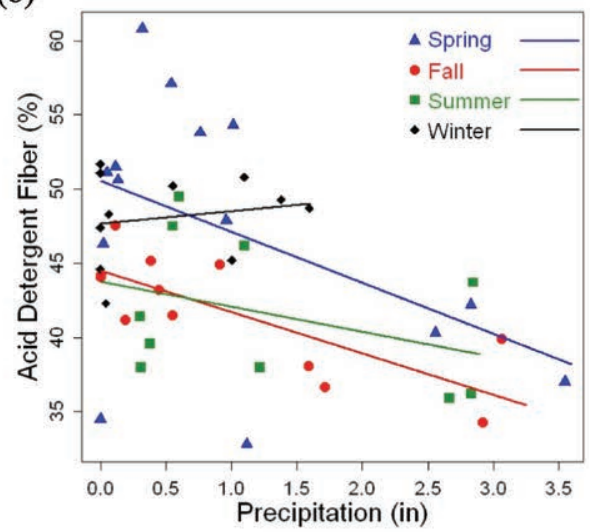

Figure 4. Forage crude protein (Fig. 4a) and acid detergent fiber (Fig. 4b) modeled as a function of current monthly precipitation with season as a classification variable; see Table 2 for regression equations.

a variety of effects on forages. Quality may be increased or decreased depending on the stage of forage maturation and precipitation events. Moderate stress causes a reduction in stem growth; consequently, the forage has a higher leaf-tostem ratio which results in a higher quality plant when compared to a nonstressed plant. If there is severe water stress due to drought, the overall forage quality is reduced because of senescence. ${ }^{12}$ Precipitation was quite variable over the six years of our study, including multiple drought events. These droughts, coupled with tropical moisture events, were likely contributing factors to the low level of predictability based solely on precipitation (Fig. 2).

\section{Seasonal Effects}

It is reasonable to assume that forage nutritive value is also affected by season of growth. Season can greatly impact plant growth rate, stage of maturity, regrowth potential, leaf-to-stem ratio, lignin deposition, and various other factors that con- tribute to changes in plant nutritive value. ${ }^{13}$ To account for seasonal effects, we modeled our data as a function of current monthly precipitation with season of growth for each season. When we analyzed forage CP using current monthly precipitation and season (Fig. 4a), the models that include spring and fall accounted for $48 \%$ and $62 \%$ of the variation in forage $\mathrm{CP}$, respectively; however, it was clear that forage $\mathrm{CP}$ was not highly correlated with precipitation for the summer or winter, accounting for less than $3 \%$ of the variation in CP each season (Table 2). Summer and winter may not be highly correlated with $\mathrm{CP}$ because of extreme temperature or prolonged drought that caused plants to go dormant or senesce during this sixyear study, preventing a good growth response when rainfall events did occur.

When we compared forage ADF with current month's precipitation in each season (Fig. 4b), a greater amount of variation in forage $\mathrm{ADF}$ could be accounted for in the fall when compared to the spring, summer, and winter (Table 2).

Table 2. Simple linear regression of forage nutritive value metrics, crude protein and acid detergent fiber, compared to five different precipitation models $(n=14,12,10$, and 11 for spring, fall, summer, and winter, respectively)

\begin{tabular}{|l|c|c|c|c|}
\hline \multirow{2}{*}{ Season } & \multicolumn{2}{|c|}{ CP } & \multicolumn{2}{c|}{ ADF } \\
\cline { 2 - 5 } & Equation* & Adjusted $r^{2}$ & Equation & Adjusted $r^{2}$ \\
\hline Spring & $\hat{Y}=6.10+2.03 \mathrm{X}_{1}$ & 0.48 & $\hat{\gamma}=50.58-3.43 \mathrm{X}_{1}$ & 0.15 \\
\hline Summer & $\hat{Y}=9.09+0.36 \mathrm{X}_{1}$ & $\leq 0.03$ & $\hat{\gamma}=43.76-1.69 \mathrm{X}_{1}$ & 0.03 \\
\hline Fall & $\hat{Y}=6.99+2.67 \mathrm{X}_{1}$ & 0.62 & $\hat{\gamma}=44.48-2.78 \mathrm{X}_{1}$ & 0.57 \\
\hline Winter & $\hat{Y}=6.87+0.42 \mathrm{X}_{1}$ & $\leq 0.03$ & $\hat{\gamma}=47.71+0.84 \mathrm{X}_{1}$ & $\leq 0.03$ \\
\hline${ }^{*} \mathrm{X}_{1}$ indicates current month precipitation. & & & \\
\hline
\end{tabular}


Table 3. Multiple linear regression equations for predicting crude protein and acid detergent fiber from temperature and precipitation in fall and spring seasons ( $n=13$ and 11 for spring and fall, respectively)

\begin{tabular}{l|c|c|c|c|}
\hline \multirow{2}{*}{ Season } & \multicolumn{2}{|c|}{ CP } & \multicolumn{2}{c|}{ ADF } \\
\cline { 2 - 5 } & \multicolumn{1}{|c|}{ Equation } & Adjusted & Equation & $\begin{array}{c}\boldsymbol{R}^{2} \\
\boldsymbol{R}^{2}\end{array}$ \\
\hline Spring & $\hat{Y}=8.53+2.08 \mathrm{X}_{1}-0.03 \mathrm{X}_{2}$ & 0.44 & $\hat{Y}=54.36-3.35 \mathrm{X}_{1}-0.05 \mathrm{X}_{2}$ & 0.07 \\
\hline Fall & $\hat{Y}=-4.63+1.92 \mathrm{X}_{1}+0.17 \mathrm{X}_{2}$ & 0.63 & $\hat{Y}=70.93-1.08 \mathrm{X}_{1}-0.38 \mathrm{X}_{2}$ & 0.73 \\
\hline$* \mathrm{X}_{1}$ indicates average monthly precipitation by season; $\mathrm{X}_{2}$, average monthly temperature by season. & \\
\hline
\end{tabular}

The autumn has higher forage nutritive value when rainfall is adequate due to the forages having more $\mathrm{CP}$ and less $\mathrm{ADF}$ relative to other seasons of the year.

Our results suggest that fall and spring are times of the year when a portion of the change in forage nutritive value can be predicted with precipitation using regression analysis. This is likely due to higher amounts of precipitation during September and May in south Texas ${ }^{11}$ which allow for more predictable growth patterns. Smart et al. ${ }^{5}$ noted that in western South Dakota, spring (April-June) precipitation was highly correlated to annual forage production. The authors proposed that the strong correlation was related to the fact that $48 \%$ of the region's annual precipitation falls between April and June. ${ }^{5}$ This concept may explain why the spring and fall in our current study account for a larger amount of variation than summer and winter.

(a)

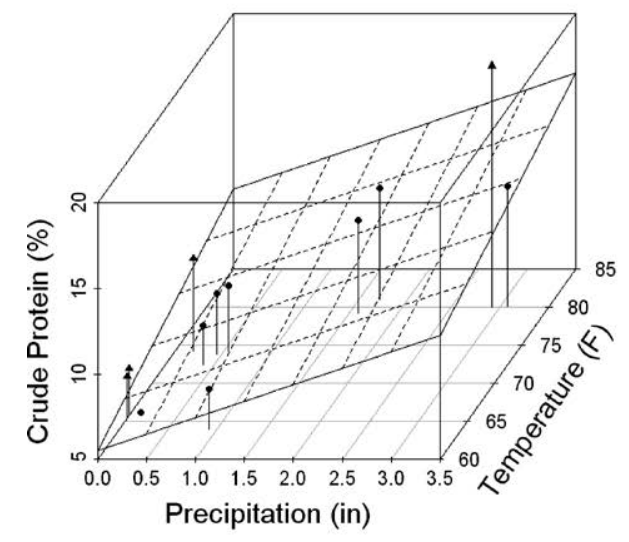

$\Delta$ - Points that lie above the regression plane.

- - Points that lie below the regression plane.
Extreme precipitation variation during this time frame likely contributed to the resulting variability between forage nutritive value parameters and precipitation (Fig. 2). In more predictable precipitation areas, such as the Northern Great Plains, possibly more variation can be accounted for when using seasonal precipitation data. White ${ }^{14}$ reviewed six studies from the Northern Great Plains and found that forage yield was highly correlated with April and May precipitation events. Wiles et al. ${ }^{6}$ also found that precipitation between April and June could be used to predict peak standing forage yield with relative accuracy for multiple sites in the Northern Great Plains.

\section{Temperature Effects}

The final modeling technique incorporated a third variable, temperature, to be analyzed along with precipita-

(b)

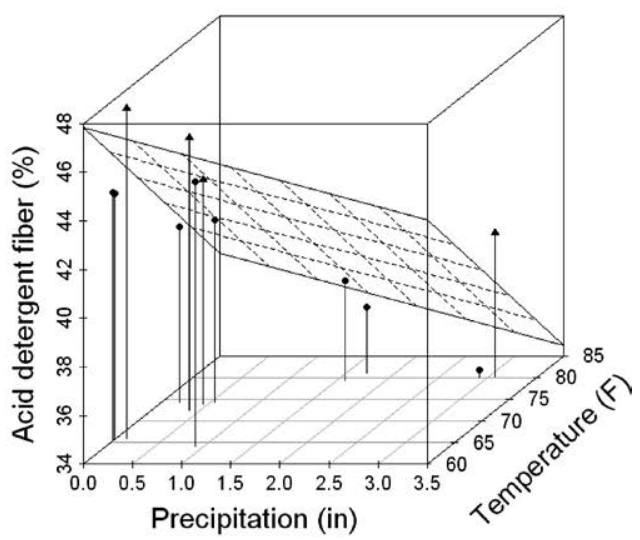

Figure 5. Multiple linear regression used to explain variation in forage crude protein (Fig. 5a) and acid detergent fiber (Fig. 5b) during the fall season with independent variables being current monthly precipitation and average temperature; see Table 3 for regression equations. 
tion for each season of growth. According to Thomas and Osenbrug, ${ }^{15}$ when daily temperature was correlated with April to June precipitation, $84 \%$ of the forage production could be accounted for when compared to precipitation alone (which accounted for $53 \%$ of the variation). Based on the findings of the previous two models, fall had the most potential to be correlated with environmental variables. When average monthly temperature and precipitation during the fall season were included in the model, little additional variation in forage $\mathrm{CP}$ was accounted for (Table 3; Fig. 5a). However, the inclusion of monthly temperature in the ADF analysis increased the predictability of that variable (Fig. 5b), by accounting for $73 \%$ of the variation in forage $\mathrm{ADF}$ when compared to monthly precipitation alone (57\%, Table 2; Fig. 4b). Results suggest that this statistical approach may be useful for predicting certain forage nutritive value metrics in the fall based on easily attainable weather data.

When the spring season was analyzed using the same approach, the inclusion of temperature did not account for any additional variation in forage $\mathrm{CP}$ or ADF (Table 3). Based on these findings, we did not conduct an additional analysis of summer and winter seasons given that temperature did not account for a significant amount of the variation in the fall or spring models. Because temperature is highly correlated with season, ${ }^{12}$ variation that may be associated with temperature alone was accounted for with the addition of the seasonal classification model.

\section{How to Use What We Learned}

The current production stage will determine the minimum nutrient requirements of cattle. Maintenance requirements for $\mathrm{CP}$ of dry cows are 6-8\% CP, whereas lactating cows require $9-12 \%$ CP. ${ }^{9}$ Likewise, ADF requirements average $42 \%$ for dry cows and $39 \%$ for lactating cows, ${ }^{16}$ with corresponding TDN requirements equal to $52-54 \%$ and $55-56 \%$ for dry and lactating cows, respectively.

Based on regression equations in Table 2 for the fall, one inch of precipitation would result in a consumed forage value of $9.7 \% \mathrm{CP}$ and $42 \% \mathrm{ADF}$, which would meet the nutritional requirements of dry cows. Two inches of monthly precipitation in the fall would provide approximately $12.3 \% \mathrm{CP}$ and $39 \% \mathrm{ADF}$ for lactating cows during that time period, meeting their nutrient requirements. In south Texas, ranchers typically start supplementing $\mathrm{CP}$ in late October/November when forage nutritive value declines below animal nutrient requirements and cease supplementation when forage nutritive value increases with spring growth (Fig. 1). In this example, south Texas ranchers should consider supplementing earlier in the fall if monthly precipitation is less than one to two inches (given calving season) and delay supplementation if monthly precipitation is greater than two inches. Weather parameters in south Texas may help ranchers determine when to start supplementing the cow herd in the fall, but they are not as useful in predicting when supplementation should be stopped in the spring.
The approach to predict forage nutritive value that we used in this study can be applied to other regions. The outcome of the analysis may be vastly different given precipitation (patterns, timing, and amounts), seasonal temperatures, and the forage species that characterize that region's rangeland. Smart et al. ${ }^{5}$ noted that native rangeland has higher species diversity and would be less predictable when compared to a seeded pasture using the same limited climatic variables. Species diversity on rangelands could certainly limit the amount of variation that could be accounted for using this methodology since different forage species have different growth patterns, production potentials, cattle consumption levels and nutritive values. Multiple forage species were collected in this study and composited as one sample which may have added to the variation in detectable forage nutritive values.

Monthly precipitation and temperature in the fall accounted for $63 \%$ and $73 \%$ of the variation for $\mathrm{CP}$ and $\mathrm{ADF}$, respectively. In similar studies, ${ }^{5,14}$ spring was the most promising season to use. As a result, if weather parameters can be used reliably to identify the point where forage nutritive value no longer meets animal nutrient requirements, then ranchers can provide supplementation at the correct time. Strategic supplementation should reduce unnecessary costs associated with supplementation when forage nutritive value is adequate or with lost production when supplementation begins too late.

\section{Management Implications}

The purpose of our study was to determine if forage quality (CP and $\mathrm{ADF}$ ) in south Texas could be reasonably predicted using easily obtained weather factors. Unfortunately, a model based on precipitation alone did not provide a reliable estimation of forage nutritive value; however, categorizing the data by season allows a more reliable estimation of forage nutritive value for certain times of the year. This information is readily available to ranchers and can be easily applied to their specific locale. This can be especially useful during those "transition" months when forage nutritive value is marginal. Providing supplementation at times when the cow herd needs it, and stopping supplementation when forage nutritive value is adequate, is a cost-effective approach to cattle supplementation.

\section{References}

1. Gonzalez, C. L., And J. H. Everitt. 1982. Nutrient contents of major food plants eaten by cattle in the South Texas Plains. Journal of Range Management 35(6):733-736.

2. Aguiar, A. D., L. O. Tedeschi, F. M. Rouquette, K. McCuistion, J. A. Ortega-Santos, R. Anderson, D. DeLaney, and S. Moore. 2011. Determination of nutritive value of forages in south Texas using an in vitro gas production technique. Grass and Forage Science 66:4.

3. Allen, V. G., and E. Segarra. 2001. Anti-quality components in forage: overview, significance, and economic impact. Journal of Range Management 54(4):409-412. 
4. McCollum, T. 1995. The latest methods to determine when to supplement. In: Proceedings of the Range Beef Cow Symposium XIV; 5-7 December 1995; Gering, NE, USA. Lincoln, NE, USA: Animal Science Department at DigitalCommons@ University of Nebraska - Lincoln. p. 185-189.

5. Smart, A. J., B. H. Dunn, P. S. Johnson, L. Xu, and R. Gates. 2007. Using weather data to explain herbage yield on three Great Plains plant communities. Rangeland Ecology E' Management 60:146-153.

6. Wiles, L. J., G. Dunn, J. Printz, B. Patton, and A. Nyren. 2011. Spring precipitation as a predictor for peak standing crop of mixed-grass prairie. Rangeland Ecology \& Management 64:215-222.

7. Meyer, M.W., And R. D. Brown. 1985. Seasonal trends in the chemical composition of ten range plants in south Texas. Journal of Range Management 38:154-157.

8. De Vries, M.W. 1995. Estimating forage intake and quality in grazing cattle: a reconsideration of the hand-plucking method. Journal of Range Management 48:370-375.

9. Holechek, J. L., R. D. Pieper, and C. H. Herbel. 1995. Range animal nutrition. In: J. L. Holechek, R. D. Pieper, and C. H. Herbel [EDs.]. Range management principles and practices. 2nd ed. Englewood Cliffs, NJ, USA: Prentice-Hall, Inc. p. 325-370.

10. Schroeder, J. W. 1994. Interpreting Forage Analysis. AS1080. Available at: http://hdl.handle.net/10365/9133. Accessed 18 June 2012.

11. Everitt, J. H., C. L. Gonzalez, G. Scott, and B. E. Dahl. 1981. Seasonal food preferences of cattle native range in the south Texas Plains. Journal of Range Management 34:384-388.
12. Mueller, S. C. and S. B. Orloff. 1994. Environmental factors affecting forage quality. In: Proceedings of the 24th California Alfalfa Symposium; 8-9 December 1994; Redding, CA, USA. Davis, CA, USA: University of California, Davis. p. $56-62$.

13. Van Soest, P. J. 1994. Nutritional Ecology of the Ruminant. 2nd ed. Ithaca, NY, USA: Cornell University Press.

14. White, L. M. 1985. Stand age, precipitation, and temperature effects on forage yield. Journal of Range Management 38:39-43.

15. Thomas, J. R. and A. Osenbrug. 1959. Effect of manure, nitrogen, phosphorus, and climatic factors on the production and quality of bromegrass-crested wheatgrass hay. Agronomy Journal 51:63-66.

16. Rayburn, E. 2002. Use Forage Test To Diagnose Management Problems. West Virginia University Extension Service. Available at: http://www.wvu.edu/ agexten/forglvst/foragtst.htm. Accessed 6 July 2012.

Authors are Associate Professor, King Ranch Institute for Ranch Management, kim.mccuistion@tamuk.edu (McCuistion), Graduate Assistant, Dept of Animal, Rangeland and Wildlife Sciences (Grigar), Professor, Caesar Kleberg Wildlife Research Institute (Wester), Assistant Professor, King Ranch Institute for Ranch Management (Rhoades), Director and Professor, King Ranch Institute for Ranch Management (Mathis), Texas AEMM University-Kingsville, Kingsville, TX 78363, USA; and Professor, Dept of Animal Science, Texas AE'M University, College Station, TX 77843-2471,USA (Tedeschi). 